胸腔鏡下に修復した肝細胞癌に対するラジオ波焼灼術後の 横隔膜ヘルニアの 1 例

\author{
田中 里奈*1, 桑田陽一郎*2, 沖重 有香*3 \\ 石川 浩之*1, 大竹 洋介*1, 青木 稔*1
}

\begin{abstract}
要旨
症例は 80 歳女性で, 主訴は呼吸困難. 肝細胞癌に対して, ラジオ波焼灼術 (RFA) や肝動脈塞栓術を当院で繰り返してい る. CT で右胸水貯留と, 横隔膜欠損部を通しての右胸腔内への腸管脱出を指摘された. 腹壁に門脈圧立進に伴う怒張血管を 認め, かつ肝の委縮は高度であった. イレウス症状は認めなかった. RFA 後の横隔膜へルニアが疑われ，手術を行う方針と なった. 過去の MRI を検討すると, 肝 S6 病変に対する RFA 時に横隔膜に熱損傷が加わり, その部位が断裂しへルニアを発 症したと考えられた．上腹部手術操作や腹壁の怒張血管損傷による肝不全のリスクを考慮し，胸脘鏡下手術 (VATS) を行い 修復することとした．結腸や大網を腹腔内に環納し， $3 \mathrm{~cm}$ 大の横隔膜欠損部は直接縫合で修復した．VATSは本手術の有用 なアプローチの 1 つと考えられた.
\end{abstract}

索引用語 : 肝硬変, 肝細胞癌, ラジオ波焼灼術, 横隔膜ヘルニア, 胸腔鏡下手術 liver cirrhosis, hepatocellular carcinoma, radiofrequency ablation, diaphragmatic hernia, video-assisted thoracic surgery

\section{はじめに}

ラジオ波焼灼術 (Radiofrequency ablation 以下 RFA）は，肝細胞癌に対し広く行われるようになった局 所治療法である。その遅発性合併症として, 横隔膜へル ニアが報告されている. 今回, RFA 後の横隔膜ヘルニア の修復に, 胸腔鏡下手術 (Video-assisted thoracic surgery 以下 VATS）が有用であった 1 例を経験したため報告す る.

\section{症例}

患 者 : 80 歳, 女性.

主 訴：呼吸困難.

\footnotetext{
*1西神戸医療センター呼吸器外科

*2同 放射線科

*3同 消化器科

原稿受付 2012年 8 月 6 日

原稿採択 2012年 8 月 31 日
}

既往歴：55 歳時に右乳癌 (手術). 61 歳時より C 型肝 硬変. 65 歳時より糖尿病（食事療法のみ）. 78 歳時より 肝細胞癌 (HCC) を指摘され, 当院消化器科, 放射線科 で RFA や肝動脈塞栓術を施行している.

現病歴：肝 S8 の $\mathrm{HCC}(2 \mathrm{~cm})$ に対し, 2009 年 7 月に RFA 施行 (Cool-tip 針, 出力 $60 \mathrm{~W})$. 同病変の再発に対 し， 2009 年 12 月に RFA を施行（Cool-tip 針, 出力 75 $\mathrm{W})$. 肝 $\mathrm{S} 6$ の $\mathrm{HCC}(9 \mathrm{~mm})$ に対し, 2011 年 1 月に RFA を施行 (Cool-tip 針, 出力 $60 \mathrm{~W}) .2012$ 年 1 月, 胸椎圧迫 骨折により他院に入院した。呼吸困難を訴えたために施 行した胸部 CT で横隔膜ヘルニアが疑われ，2012 年 2 月，当院に転院となった.

入院時現症 : 身長 $149 \mathrm{~cm}$, 体重 $49 \mathrm{~kg}$, 体温 $37.2^{\circ} \mathrm{C}$, 血 圧 $124 / 60 \mathrm{mmHg}$, 脈拍 $90 / \mathrm{min}$ (整), $\mathrm{SpO}_{2}$ は経鼻 $1 \mathrm{~L}$ の酸素投与下で $95 \%$ であった. 右呼吸音は減弱, 腹部は やや膨満していた.

血液検査 : 貧血や炎症所見は認めなかった。血小板は $12.0 \times 10^{4} / \mu \mathrm{l}, \mathrm{PT}$ は $78.0 \%$ と低下していた. Albは 2.1 
$\mathrm{g} / \mathrm{dl}$ と低下しており, T-Bil $1.1 \mathrm{mg} / \mathrm{dl}$, GOT 46 IU/l, GPT $35 \mathrm{IU} / 1$ と軽度高值であった. 腎機能や電解質は異常がな かった. 1 L 酸素投与下の血液ガス分析は, pH 7.489, $\mathrm{HCO}_{3} 30.6 \mathrm{mmol} / \mathrm{l}, \quad \mathrm{pO}_{2} 64.2 \mathrm{mmHg}, \quad \mathrm{pCO}_{2} 41.2 \mathrm{mmHg}$ であった. HbAlc は $5.5 \%$ で糖尿病のコントロールは良 好であった。

胸部 X 線写真 (Fig. 1)：右肺野の透過性低下を認め, 右胸腔内に腸管ガスの存在が疑われた.

胸腹部造影 CT（Fig. 2）：右胸腔内に胸水貯留してお

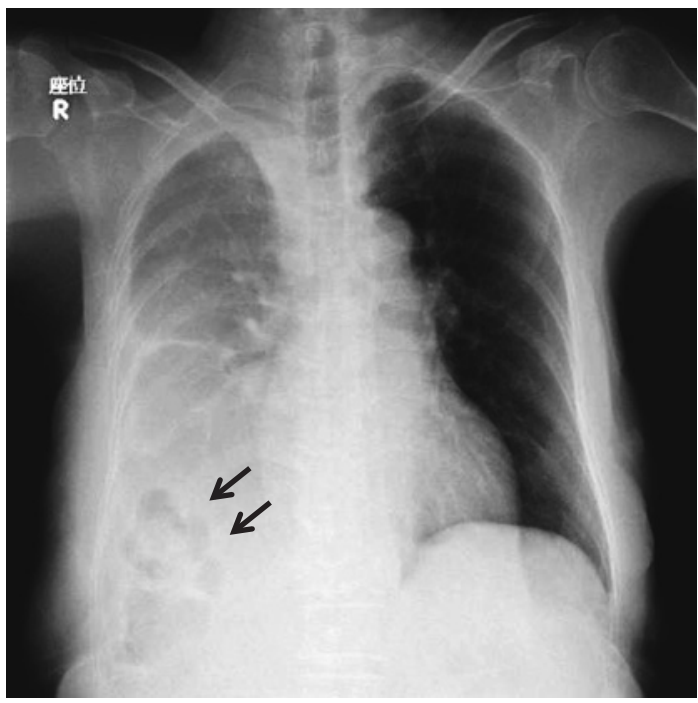

Fig. 1 Chest radiograph showed pleural effusion, and the existence of bowel gas in the thoracic cavity was suspected (arrows).
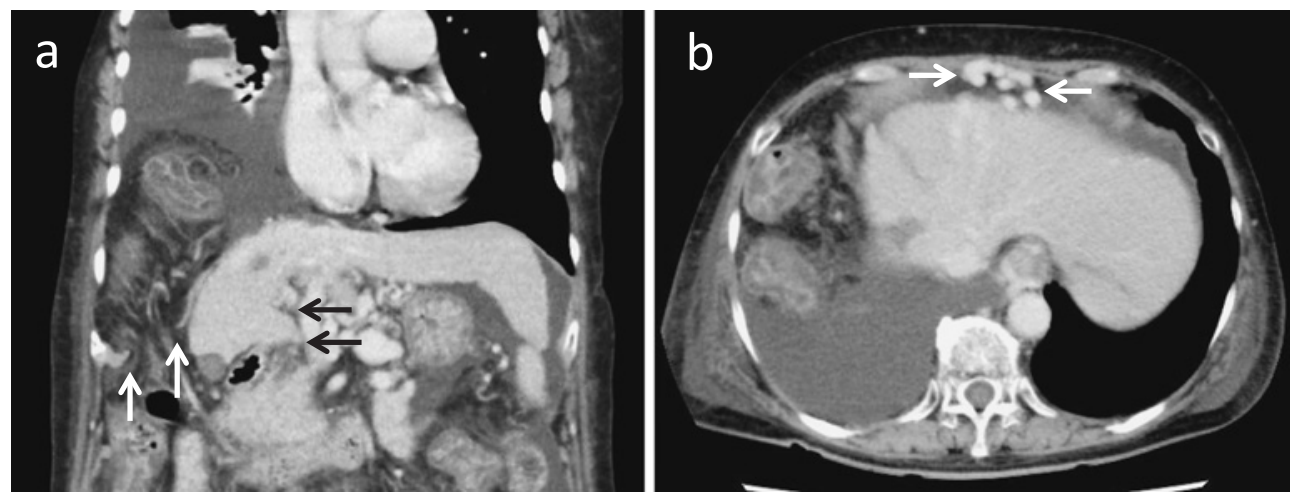

Fig. 2 (a) Enhanced computed tomography revealed a loop of the large intestine in the thoracic cavity passing through the defect of the diaphragm. Severe atrophy of the liver was also recognized. The diaphragmatic defect and atrophic liver are shown by white and black arrows, respectively. (b) The vessels in the abdominal wall were overswelled (arrows).
り，右下葉は無気肺となっていた，横隔膜欠損部を通し て結腸や腹腔内脂肪組織が右胸腔に脱出していた.また, 肝右葉は高度に委縮しており，腹壁や腹胿内には，門脈 圧立進に伴って側副血行路として発達した怒張した血管 を認めた。

入院後経過：イレウスを疑う腹部症状は認めず，転院 1 週間後に手術を行う方針となった。手術 3 日前より絶 食とし，補液を行った．本例の Child-Pugh 分類は class B (9 点)であった．腹壁に発達した側副血行路の損傷や 上腹部手術操作による肝不全のリスクを考慮し，また， 腸切除は要しないと判断したことから，VATSで手術を 行う方針となった.

手術所見（Fig. 3）:右第 7 肋間に $4 \mathrm{~cm}$ の小切開を抒 き, 1 ウィンドウ 2 ポートで手術を行った. 胸腔内には漿 液性の胸水貯留と，結腸や大網の脱出を認めた。腸管は 虚脱しており，少しずつ腹腔内に環納した。横隔膜腹側 の筋層部に $3 \mathrm{~cm}$ 大のヘルニア門を認めた．横隔膜の緊 張はなく，かつ，ヘルニア門周囲の横隔膜の色調も正常 であったため，トリミングせずに直接縫合が可能と判断 した。吸収性ポリグリコール酸（PGA）フェルト（ネオ ベールシート $\left.{ }^{\circledR}\right)$ をプレジェットとして吸収糸で 6 針 マットレス縫合を行い，ヘルニア門を閉鎖した．横隔膜 面を観察したが，ヘルニア以外には明らかな異常所見は なかった，肝硬変患者でもあったため，肝性胸水の予防 として，横隔膜面全体に PGA シートを貼付してフィブ リン糊をスプレーで塗布した

術後経過：肺の拡張は良好で, 術後 2 日目に胸喀ド 

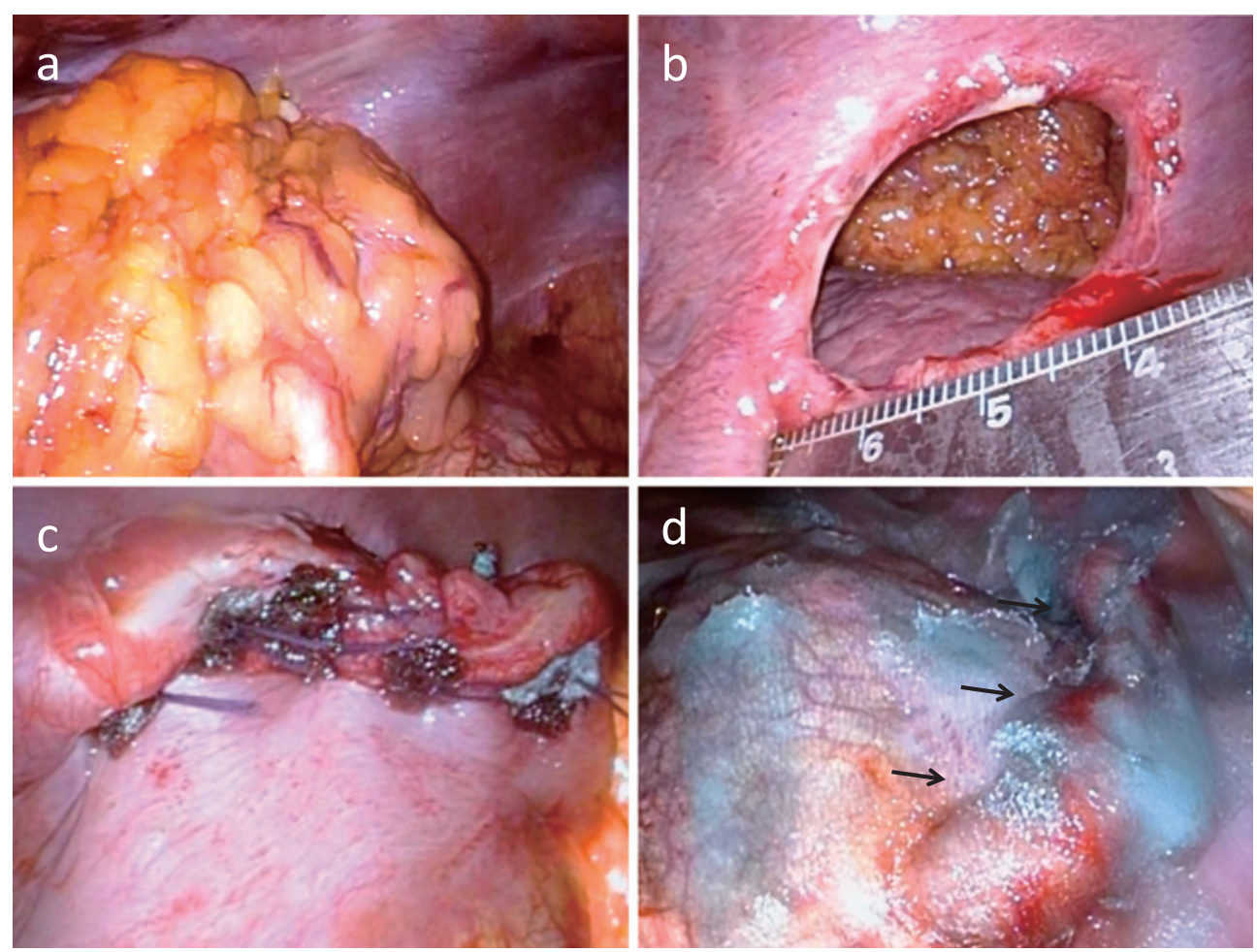

Fig. 3 (a) The large intestine and greater omentum had herniated into the thoracic cavity. (b) A diaphragmatic defect of about $3 \mathrm{~cm}$ in size was observed. (c) The defect was repaired by pledgeted mattress suture. (d) The diaphragm was entirely covered with a polyglycolic acid sheet and fibrin glue. The suture line of the diaphragm is shown with arrows.

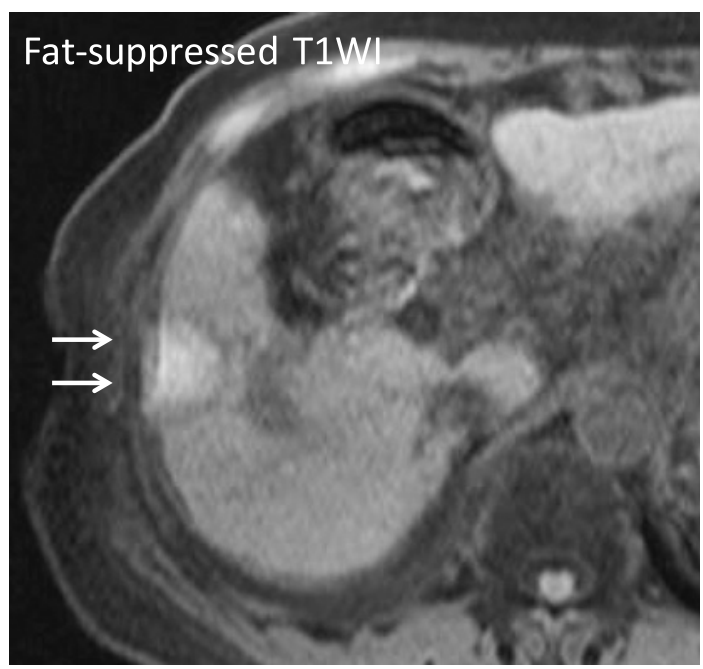

Fig. 4 Magnetic resonance imaging (MRI) 1 day after RFA for S6 HCC showed diaphragmatic damage along the ablation area (arrows).
レーンを抜去した.リハビリを進め, 術後 20 日目に退院 した. 術後 5 力月経過するが, 再発は認めていない. 2011 年 1 月の肝 S6 HCC に対する RFA 後の Magnetic resonance imaging (MRI) を検討した. RFA 後翌日の脂肪抑 制 T1 強調画像（Fig. 4）で焼灼部に接する横隔膜が高信 号を示し, 熱損傷が疑われた.さらにRFA 後 8 力月目の $\mathrm{T} 2$ 強調画像 (Fig. 5) では, 横隔膜に断裂を疑う久損部を 認めた (矢印部). 肝 S6への RFA 時の熱損傷が今回の横 隔膜ヘルニアの誘因と考えられた.

\section{考察}

HCC に対する RFA は, 超音波ガイド下に経皮的に腫 瘍を穿刺し焼灼する優れた局所制御能を有する治療法 で，広く行われるようになってきた。電極近傍組織にお ける蒸発・炭化といった変化を抑制するシステムによ り，通電中の組織抵抗の上昇を抑え，多くのエネルギー を長い時間にわたって伝播し, 病変を確実に凝固壊死さ せることを可能とする。 その低侵襲性も広く普及した一 

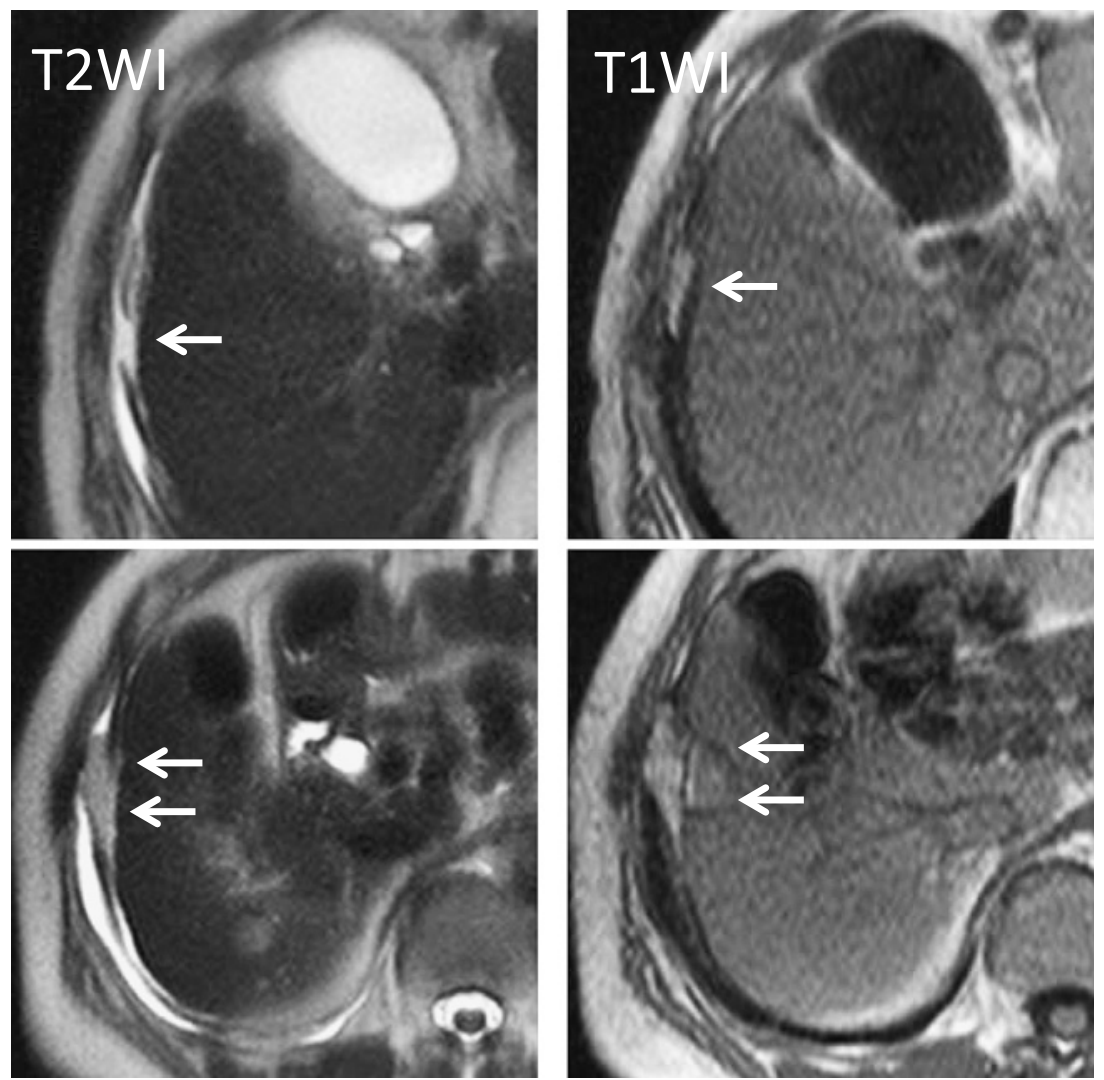

Fig. 5 MRI 8 months after RFA for S6 HCC revealed the defect of the diaphragm (arrows).

因と考えられるが, 手技に伴う合併症には注意が必要で, 出血や胆管損傷, 他臓器損傷, 肝膿瘍, 皮膚熱傷などが 報告されている ${ }^{1)}$. また, RFA 後の遅発性合併症として, 横隔膜ヘルニアの報告が近年散見される.

我々の検索しえた限りでは, 本邦での RFA 後横隔膜 ヘルニアの報告は本症例を含めると 15 例であった ${ }^{2 \cdot 14)}$. 平均年齢 69.1 歳 (48 84 歳), 男性 10 例・女性 5 例, RFA から発症までの期間は平均 16.6 力月（6３6 カ 月）であった。この合併症が遅発性である理由は, RFA 時の熱損傷で横隔膜に脆弱な部分が生じ，これに肝硬変 による組織修復能の低下や腹水貯留による腹圧上昇, 肝 の委縮進行といった要素が加わりへルニアを発症するか らと考えられている. 本例の RFA 後の MRI 所見を検討 すると, 前述の通り, 肝 S6 に対する RFA 時の熱損傷が 横隔膜ヘルニアの誘因と考えられた。本例でも RFA か ら横隔膜ヘルニアの発症までは 1 年以上の期間があり, 過去の報告例と合致している.

本邦報告 15 例中，手術は 12 例に施行していた。腸管
が嵌頓壊死して腸切除を要した例は 5 例あった。うち 2 例が在院死しており，生存しても術後合併症の発症で長 期入院を要することが多い。腸管が嵌頓し腸切除を要す る場合は非常にリスクが高い手術といえ，その前に修復 術を行うべきと思われる，手術を行わず経過観察した症 例は 3 例あり,うち 2 例は死亡している. 2 例ともイレウ スを発症していたが，高齢であることや心肺機能・肝機 能低下を理由に手術を行わなかった症例であった。アプ ローチに関しては，開腹手術がほとんどであるが，國光 らは $8 \mathrm{~cm}$ の小開胸でアプローチし，良好な視野の元で 修復が可能であったと報告している ${ }^{14)}$. 腸管切除が必要 となる可能性がある場合は, 開腹でアプローチすべきで あるが，経胸腔でのアプローチの利点としては，肝臓が 視野の妨げにならないために確実な修復ができることが 挙げられる.

Child-Pugh 分類は, 脳症, 腹水, 血清アルブミン值, 総ビリルビン值を用いて肝臟の合成能や代謝能を総合的 に判断し肝予備能を評価する指標で class A〜C に分類 
される. 本例の Child-Pugh 分類は 9 点で, class B である が class C に近いスコアであった. かつ, Fig. 2 で示した 通り, 肝臓の委縮も高度で, 門脈圧立進に伴う側副血行 路の発達により腹壁の血管が怒張していた. 開腹でのア プローチでは, これら怒張血管の損傷や, 腹部操作時の 肝血流低下による ${ }^{15}$, 術後肝不全の可能性が危惧された。 そのためにVATSを選択し, 低侵襲で安全・確実な修復 が可能であった. 絶食により腸管が虚脱していたことも, 環納を容易にした一因と考えられた。

また, 肝硬変患者は横隔膜の小孔を介して, 右胸水が 貯留し(肝性胸水), そのコントロールに難渋することが あると報告されている ${ }^{16.17)}$. 本例では横隔膜に明らかな異 常は確認できなかったが, 肝性胸水予防のため ${ }^{17)}$, 横隔膜 面全体に PGA シートを貼付しフィブリン糊を塗布し た. VATSで良好な視野の元, 安全に, 修復術やPGA シートの被覆が施行可能であった.

\section{結語}

RFA 後の横隔膜ヘルニアに対し, VATS で修復した 1 例を経験した. RFA 後の MRIにより RFA 時の熱損傷 が横隔膜ヘルニアの原因と考えられた. VATSによるア プローチが有用であった.

\section{謝辞}

本例の診療や本論文執筆に際し, 貴重な助言をしてい ただいた, 当院放射線科・難波富美子先生, 当院消化器 科・井谷智尚先生に深謝いたします。

\section{文献}

1. 寺谷卓馬, 池原 孝, 住野泰清. 合併症とその対策. 沖田 極, 小俣政男編. 肝癌のラジオ波焼灼療法. 東京 : 医学書 院 ; 2001: 50-65.

2. Koda M, Ueki M, Maeda N, Murawaki Y. Diaphragmatic perforation and hernia after hepatic radiofrequency ablation. AJR Am J Roentgenol 2003; 180: 1561-2.

3. 河合健吾, 矢田 豊, 平野克治, 安村 敏, 工藤 浩, 田 尻和人, 他. 肝細胞癌に対する人工胸水下経皮的ラジオ波 燒灼治療 13 力月後に横隔膜ヘルニアを来した 1 例. 肝臓 2005; 46: 665-6.

4. Shibuya A, Nakazawa T, Saigenji K, Furuta K, Matsunaga K. Diaphragmatic hernia after radiofrequency ablation therapy for hepatocellular carcinoma. AJR Am J
Roentgenol 2006; 186(5 Suppl): S241-3.

5. 竹内仁司, 荒田 尚, 竹原清人, 重安邦俊, 金澤 卓, 村 田 宏, 他. 経皮的ラジオ波焼灼療法後に遅発性横隔膜へ ルニアをきたした肝細胞癌の 1 例. 肝臓 2007; 48: 458-62.

6. 朝永千春, 河野 聡, 田口要人, 松永高志, 丸山俊博, 豊 島里志, 他. 肝細胞癌に対する経皮的ラジオ波焼灼術後に 生じた横隔膜へルニアの 2 症例. 肝臟 2007; 48: 529-37.

7. 酒井良博, 仁田豊生, 水谷知央, 近藤哲矢, 宮原利行, 尾 関 豊. 肝癌に対するラジオ波治療後に発症した右横隔 膜ヘルニアの 1 例. Liver Cancer 2007; 13: 160-6.

8. 村上正道, 江端英隆, 小谷裕美, 城田 誠, 斉藤玩己, 紀 野修一.ラジオ波焼灼術施行後 1 年目に横隔膜ヘルニア 嵌頓を発症した原発性肝癌の 1 例. 日臨外会誌 2007; 68: 2991-6.

9. 坂部龍太郎, 山下芳典, 平林直樹, 多幾山渉, 小林美恵, 亀岡 稔, 他. 肝細胞癌に対する経皮的ラジオ波焼灼療法 後に発症した横隔膜ヘルニア嵌頓の 1 例. 日消外会誌 2008; 41: 93-8.

10. 黒崎 亮, 若井俊文, 白井良夫, 野村達也, 丸山 聡, 石 川 卓, 他. 肝細胞癌に対する経皮的ラジオ波焼灼療法に よる遅発性横隔膜ヘルニア嵌頓の 1 例. 日消外会誌 2008; 41: 593-8.

11. 近藤礼一郎, 上野恵里奈, 清水義久, 岡村修祐, 前山泰彦, 成田高三郎, 他. 肝細胞癌に対する経皮的ラジオ波焼灼術 後に横隔膜ヘルニアを発症した 1 例. 医学と薬学 2008 ; 60: 57-9.

12. 渡邊利史, 田島秀浩, 高村博之, 谷卓, 萱原正都, 太 田哲生. 肝細胞癌に対する経皮的ラジオ波燒灼術後に横 隔膜ヘルニアを合併した 1 例. 日臨外会誌 2009; 70: 35439.

13. 名和誉敏, 望月 圭, 藥師神崇行, 濱野美奈, 糸瀬一陽, 柄川悟志, 他. 経皮的ラジオ波焼灼術施行 20 力月後に横 隔膜ヘルニアを発症した 1 例. 日消誌 2010; 107: 1167-74.

14. 國光多望, 松原寛知, 宮内善広, 奥脇英人, 蓮田憲夫, 松 本雅彦. 肝細胞癌に対するラジオ波焼灼術後に発症した 横隔膜ヘルニアの 1 例. 日臨外会誌 2012; 73: 563-7.

15. 新井善雄, 小山研二, 浅沼義博, 面川 進, 鹿嶋秋五, 高 橋貞二, 他. レーザードップラー血流計を用いた術中門脈 系臟器組織血行動態の検討. 日消外会誌 1990; 23: 65-9.

16. Lazaridis KN, Frank JW, Krowka MJ, Kamath PS. Hepatic hydrothorax:pathogenesis, diagnosis, and management. Am J Med 1999; 107: 262-7. 
17. 池田康紀, 関 哲男, 小森俊昭, 千田雅之. 難治性肝性胸

術が奏効した一例．日呼外会誌 2012; 26:64-8.

水に対して胸腔鏡下にPGA フェルトを用いた胸膜癒着

\title{
Video-assisted thoracic surgery in a patient with diaphragmatic hernia after radiofrequency ablation for hepatocellular carcinoma
}

\author{
Satona Tanaka*1, Yoichiro Kuwata*2, Yuka Okishige*3 \\ Hiroyuki Ishikawa*1, Yosuke Otake ${ }^{* 1}$, Minoru Aoki*1 \\ ${ }^{* 1}$ Department of Thoracic Surgery, Nishi-Kobe Medical Center \\ ${ }^{* 2}$ Department of Radiology, Nishi-Kobe Medical Center \\ *3 Department of Gastroenterology, Nishi-Kobe Medical Center
}

The patient was an 80-year-old woman with dyspnea. She had repeatedly undergone radiofrequency ablation (RFA) and transcatheter arterial embolization for hepatocellular carcinoma (HCC) associated with type C cirrhosis in our hospital. Computed tomography revealed right pleural effusion and that the large intestine had herniated into the thoracic cavity through the defect of the diaphragm. Overswelled vessels in the abdominal wall due to portal hypertension and severe atrophy of the liver were also recognized. No signs of ileus were observed. Diaphragmatic hernia after RFA was suspected, and surgery was performed. Magnetic resonance imaging after RFA for an S6 lesion revealed that the diaphragm had been damaged by the heat of the ablation and was torn. That was considered to be the cause of the diaphragmatic hernia. Laparotomy would increase the risk of postoperative hepatic failure because it can reduce the hepatic blood flow and injure the abnormal vessels of the abdominal wall. Video-assisted thoracic surgery (VATS) was performed. The large intestine and greater omentum were repositioned into the abdomen, and the direct closure of the diaphragmatic defect of about $3 \mathrm{~cm}$ in size was carried out. VATS was a safe and effective approach in this case.

(C) The Japanese Association for Chest Surgery (JACS) 